Proc. Indian Acad. Sci. (Chem. Sci.), Vol. 101, No. 1, February 1989, pp. 25-32.

(C) Printed in India.

\title{
Quinone studies. Part III. Metal ion-catalysed oxidation of halophenols and halonaphthols by peroxidisulphate
}

\author{
P THIRUMALAI PERUMAL and M VIVEKANANDA BHATT* \\ Department of Organic Chemistry, Indian Institute of Science, Bangalore 560012, India
}

MS received 3 June 1988; revised 21 October 1988

\begin{abstract}
Oxidation of representative halophenols and halonaphthols by peroxidisulphate has been examined. The influence of metallic ions, viz. $\mathrm{Cu}^{2+}, \mathrm{Fe}^{3+}, \mathrm{Ag}^{+}$, on the above reaction has been studied. $\mathrm{Cu}^{2+}$ ion-catalyzed oxidation gives halo-1, 4-quinones in excellent yield. Potassium bis(biureto)cuprate(III) complex also oxidises halophenols to halo-1, 4-quinones.
\end{abstract}

Keywords. Metal ion-catalysed oxidation; halophenols; halonaphthols; peroxidisulphate; halo-1, 4-quinones.

\section{Introduction}

Oxidation of phenols and phenolic derivatives is a reaction which takes place in a wide variety of environments and conditions in nature - in plants (Mayer and Harel 1979), and in animal and human tissues (Kuczenski 1973). Many complex natural products are biosynthesized through the oxidation of phenolic precursors (Woolf 1963; Taylor and Battersby 1967). Phenolic oxidation by a number of reagents has been the subject of sustained interest. With most oxidants phenols give a mixture of products, viz., quinones (Woolf 1963; Bacon and Izzat 1966; Taylor and Battersby 1967; Finkbeiner and Toothaker 1968), dihydroxy derivatives (Baker and Brown 1948; Woolf 1963; Ogata and Akada 1970), dimeric compounds (Albert 1954; Bacon and Munro 1960; Woolf 1963) and polymeric materials (Bacon et al 1954; Inove et al 1962; Woolf 1963; Taylor and Battersby 1967; Finkbeiner and Toothaker 1968). The yields of single compounds in most cases are poor. Fremy's salts (Teuber and Rau 1953; Teuber and Staiger 1955) thallium trifluoro acetate (McKillop et al 1970), hydrogen peroxide hydrochloric acid (Perumal and Bhatt 1979), periodic acid (Perumal and Bhatt 1979), cerium IV oxide-hydrogen peroxide (Barton et al 1975), and diphenyl seleninic anhydride (Barton et al 1976, 1977) are reagents which give quinones.

Ortho-blocked phenols like 2, 6-dimethyl phenol have been reacted with chromic acid (Horswill and Ingold 1966), hydrogen peroxide-copper(II) salt (Walling and Hodgdon 1958), t-butyl hydro-peroxide (Moore and Waters 1952), alkaline ferricyanide (Haynes et al 1956) and peroxysulphate-silver (I) salt (Bacon and Munro 1960) to give the corresponding diphenoquinone.

Oxidation of phenols with potassium peroxidisulphate under alkaline conditions (Baker and Brown 1948) constitutes the well-known Elbs oxidation reaction of

* For correspondence 


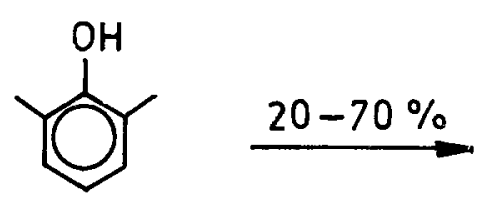<smiles>CC1=CC(=C2C=C(C)C(=O)C(C)=C2)C=C(C)C1=O</smiles>

conversion of phenols to the dihydroxy compound. Although the reaction was discovered in 1893 (Elbs 1893) it was only after 1960, that serious mechanistic work has been carried out (Behrman 1963; Ogata and Akada 1970). Evidence has been provided for the formation of sulphate esters of dihydroxy phenols (Baker and Brown 1948; Bacon et al 1954; Behrman 1963; Ogata and Akada 1970) through nucleophilic attack of phenoxide ions on the peroxy O-O bond.

There is little mechanistic investigation on the oxidation by potassium peroxydisulphate in neutral medium or in the presence of metal salts (Bacon and Izzat 1966; Bacon and Munro 1960).<smiles></smiles><smiles>O=C1C=CC=C[C@H]1[18O]OOS(=O)(=O)O</smiles>

We are reporting in this paper a study of reactions of halophenols with potassium peroxydisulphate in the presence of metallic salts. We have confined overselves to product anaiysis and have attempted to optimise the yields of the single products. Ortho- and para-blocked halophenols are easily accessible. These substituents serve to slow down dimerization and polymerization of the initially formed radicals.

\section{Results and discussion}

The main product of the oxidation of halophenols are the halo-1, 4-quinones (table 1). Of the metal salts, $\mathrm{Ag}^{+}$and $\mathrm{Fe}^{3+}$ have a marginally beneficial effect in improving the yield. In the case of the $\mathrm{Ag}^{+}$ion, its ready conversion to silver bromide probably renders it unavailable for catalyzing the oxidation reaction. The most noteworthy result is the role of the $\mathrm{Cu}^{2+}$ ion. Under favourable conditions, the yield of haloquinones is increased to above $80 \%$. In fact a highly efficient method for the preparation of halo-1, 4-quinones consists of using a copper salt as a catalyst. In all 


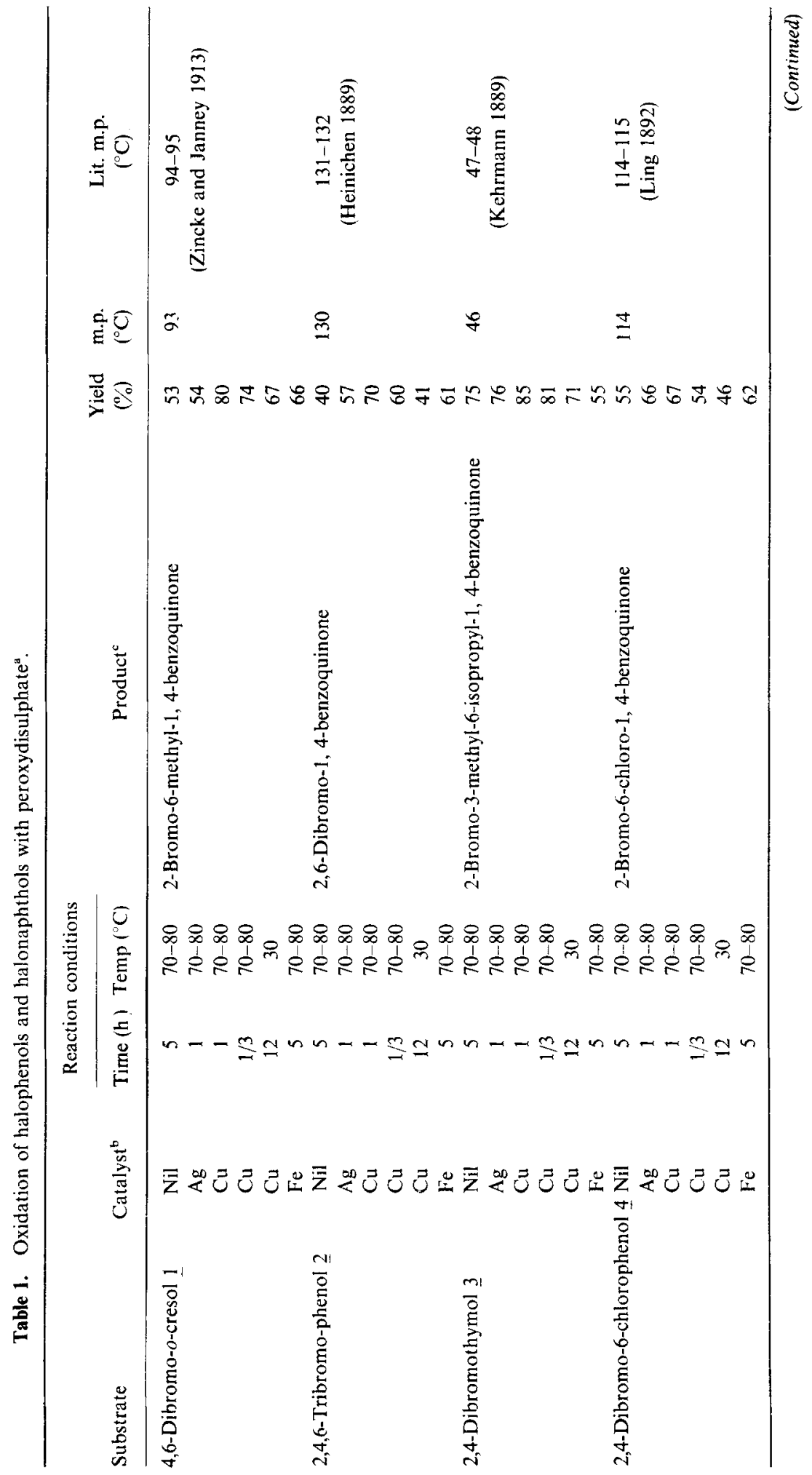




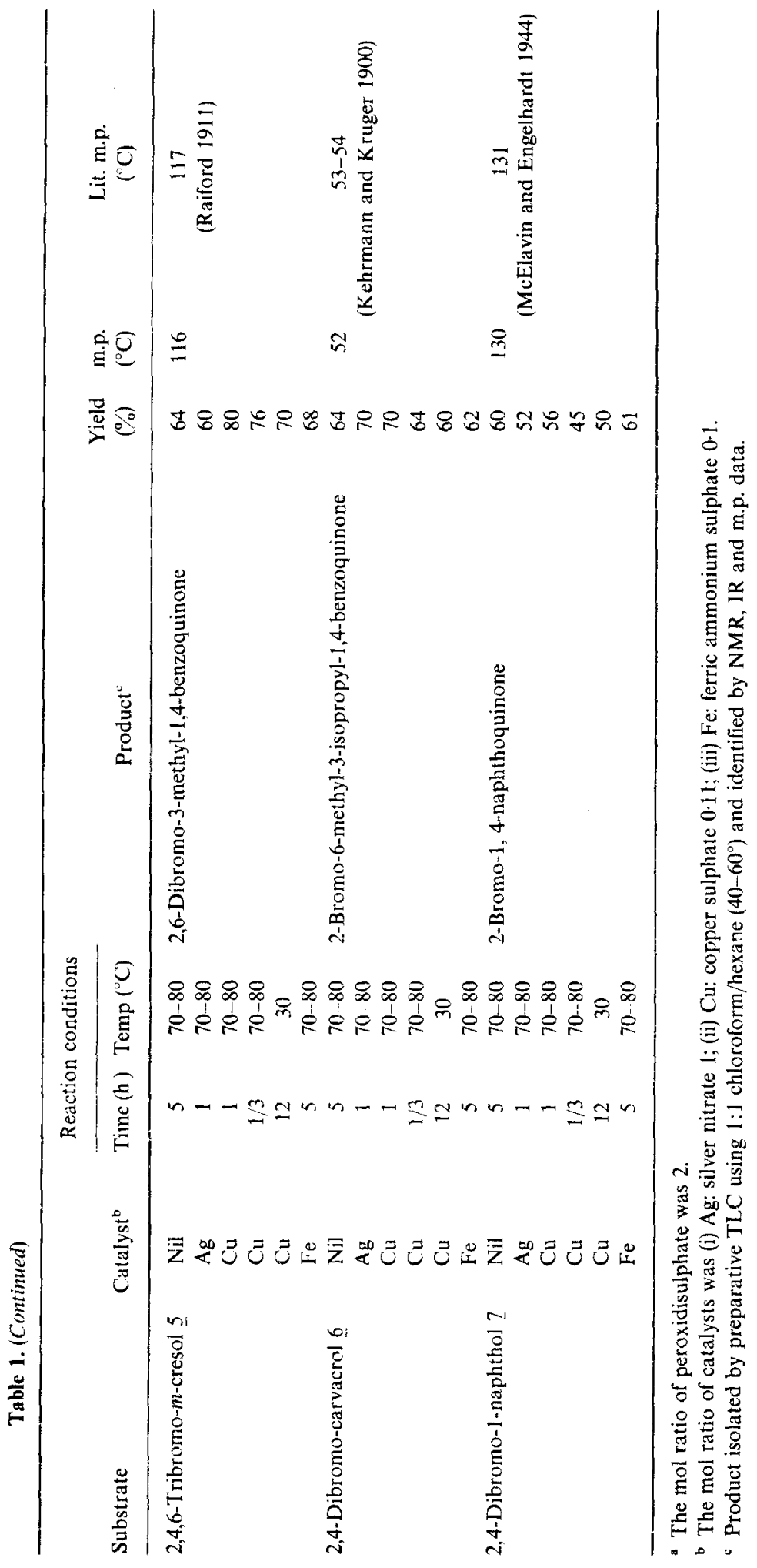


these metal-catalysed oxidations besides the halo-1, 4-quinones, some unreacted starting materials and polymeric materials could be recovered (table 2). It is clear that the system copper(II) salt-potassium peroxydisulphate is superior to peroxydisulphate itself.

Our results do not enable us to suggest a unique mechanism. Morè data is necessary before a mechanism can be advanced. Two possibilities, however, can be outlined (path A and path B, see scheme 1).

Oxidation of halophenols with potassium bis(biureto)-cuprate(III) (Gadd et al 1977) gave the corresponding halo quinones (table 3 ). These results clearly lend support to the electron transfer mechanism of path $\mathrm{A}$.

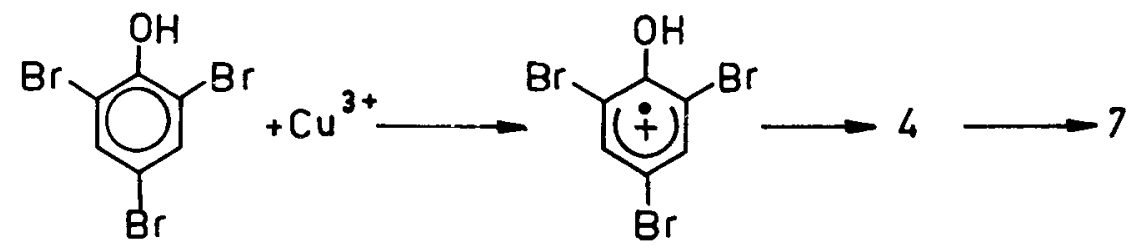

However, the question of whether all the oxidation takes place exclusively by path $\mathrm{A}$ or whether concurrent paths operate has to be answered.

Table 2. Recovery $(\%)$ of materials other than quinones.

\begin{tabular}{|c|c|c|c|c|c|c|c|c|c|c|c|c|}
\hline \multirow{2}{*}{$\begin{array}{l}\text { Starting } \\
\text { materials }\end{array}$} & \multicolumn{6}{|c|}{ Phenols $^{\mathrm{c}}$} & \multicolumn{6}{|c|}{ Polymers $^{\mathrm{d}}$} \\
\hline & $A^{h}$ & B & C & D & $E$ & $\mathbf{F}$ & A & B & $\mathrm{C}$ & D & $E$ & $\mathbf{F}$ \\
\hline 1 & 22 & 23 & 9 & 15 & 6 & 6 & 25 & 23 & 11 & 11 & 23 & 28 \\
\hline$\underline{2}$ & 30 & 14 & 12 & 23 & 26 & 12 & 30 & 29 & 18 & 17 & 33 & 27 \\
\hline$\underline{3}$ & 12 & 5 & 6 & 10 & 13 & 13 & 13 & 19 & 9 & 9 & 16 & 32 \\
\hline$\underline{4}$ & 10 & 12 & 9 & 28 & 26 & 10 & 35 & 22 & 24 & 18 & 28 & 28 \\
\hline$\overline{5}$ & 14 & 10 & 5 & 9 & 20 & 12 & 22 & 30 & 15 & 15 & 10 & 20 \\
\hline$\overline{6}$ & 10 & 4 & 8 & 15 & 14 & 8 & 26 & 24 & 22 & 21 & 26 & 30 \\
\hline 7 & 0 & 0 & 0 & 0 & 0 & 0 & 40 & 48 & 46 & 45 & 50 & 39 \\
\hline
\end{tabular}

a For the identity of the phenols see table 1

b A-F represent the methods used as follows:

A. Without catalyst; B. Ag, 1 h; C. Cu, 1 h; D. Cu, 1/3 h; E. Cu, 12 h; F. Fe, 5 h

c Isolated by preparative TLC

d Yield calculated by difference

Table 3. Oxidation of halophenols with potassium bis(biureto)cuprate(III) ${ }^{\mathrm{a}}$.

\begin{tabular}{llrr}
\hline Substrate & \multicolumn{1}{c}{ Product $^{b}$} & Yield $(\%)$ & m.p. $\left({ }^{\circ} \mathrm{C}\right)$ \\
\hline 4,6-Dibromo-()-cresol (1) & 2-Bromo-6-methyl-1, 4-benzoquinone & 56 & 93 \\
2,4,6-Tribromophenol (2) & 2,6-Dibromo-1, 4-benzoquinone & 30 & 130 \\
2,4-Dibromothymol (3) & 2-Bromo-3-methyl-6-isopropyl-1, 4-benzoquinone & 67 & 46 \\
2,4,6-Tribromo-m-cresol (ㅁ) & 2,6-Dibromo-3-methyl-1, 4-benzoquinone & 21 & 116 \\
\hline
\end{tabular}

- $4 \mathrm{~m} \mathrm{~mol}$ of $\mathrm{K} \mathrm{Cu}$ (biureto) ${ }_{2}$ and $1 \mathrm{~m} \mathrm{~mol}$ of phenol in $50 \mathrm{ml} \mathrm{of} 60 \%$ aqueous acetonitrile were stirred at $70-80^{\circ} \mathrm{C}$ for $2 \mathrm{~h}$

b The products were isolated by preparative TLC on silica gel using $1: 1$ chloroform-hexane $\left(40-60^{\circ} \mathrm{C}\right)$ as eluent 
Path A

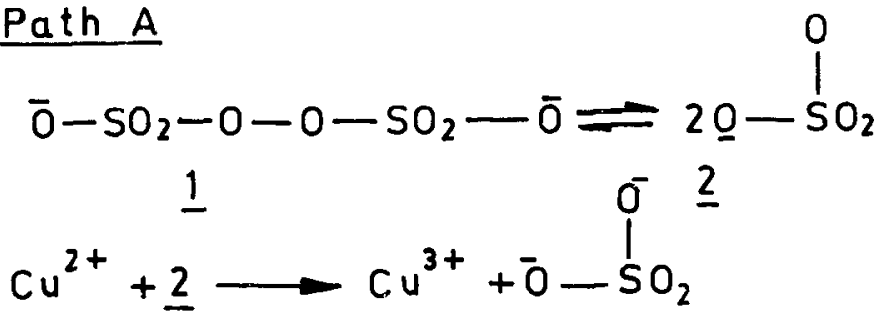<smiles>Oc1c(Br)cc(Br)cc1Br</smiles><smiles>O=C1C(Br)=CC(Br)=CC1Br</smiles><smiles>O=C1C(Br)=CC(Br)=CC1Br</smiles>

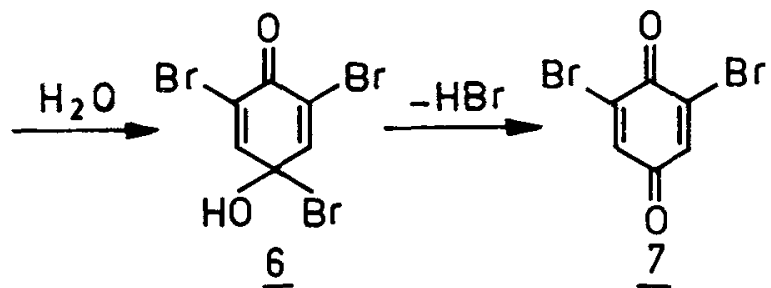

Path B

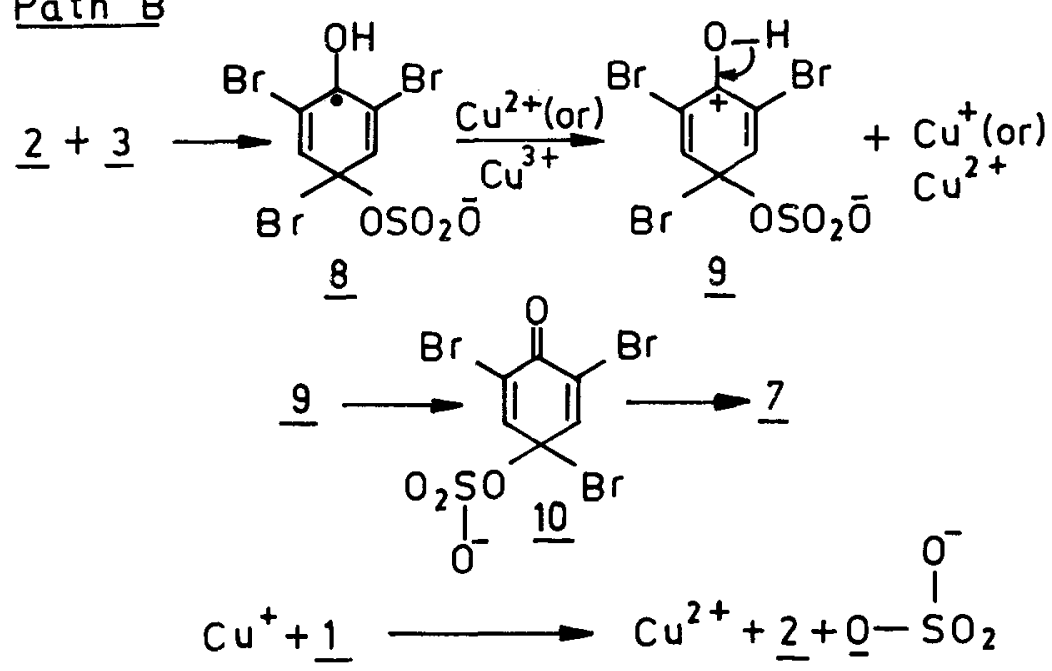

Scheme 1. 


\section{Experimental}

Melting points were determined on a Kofler hot-stage apparatus and are uncorrected. The identity of the compounds was confirmed by comparison of the IR and NMR spectra. IR spectra were recorded by the normal nujol mull techniques on a PerkinElmer model 700 spectrometer and NMR spectra were recorded in $\mathrm{CDCl}_{3}$ or $\mathrm{CCl}_{4}$ solutions on a Varian T-60 spectrometer.

The halophenols were prepared by a modified procedure (Meldola and Hughes 1890). To the phenol $(0.25 \mathrm{~mol})$ dissolved in glacial acetic acid $(100 \mathrm{ml})$, was added bromine $(0.5 \mathrm{~mol}$ or $0.75 \mathrm{~mol}$ depending upon the phenol) in $50 \mathrm{ml}$ of glacial acetic acid. It was refluxed for $2 \mathrm{~h}$ in a fume hood. The reaction mixture was then poured into $250 \mathrm{ml}$ of cold water. The product was collected by filtration if solid, then washed with water, dried and crystallized from suitable solvents. When the product was a liquid, it was extracted from the aqueous suspension with ether and washed four times with water. It was dried over sodium sulphate and the ether removed. The product was distilled under reduced pressure. The yields of the crude products were $90-95 \%$. Melting and boiling points, and spectral data of the compounds matched with those of the authentic compounds $\underline{1}$ (Claus and Jackson 1888), $\underline{2}$ (Orton et al 1907), $\underline{3}$ (Kehrmann 1889), 4 (Ling 1892), $\underline{5}$ (Jost and Richter 1923), $\underline{6}$ (Kehrmann and Kruger 1900), 7 (Meldola and Hughes 1890).

3.1 Preparative scale general procedure for the preparation of quinones: Oxidation of 4,6-dibromo-o-cresol

4,6-Dibromo-o-cresol (1) $(10.64 \mathrm{~g}, 0.04 \mathrm{~mol})$ in $200 \mathrm{ml}$ of acetonitrile was added to a solution of potassium peroxydisulphate $(21.6 \mathrm{~g}, 0.08 \mathrm{~mol})$ in $150 \mathrm{ml}$ of water and copper sulphate $(1 \cdot 1 \mathrm{~g}, 0.0044 \mathrm{~mol})$. The resulting yellow mixture was stirred at $70-80^{\circ}$ for $1 \mathrm{~h}$. The reaction mixture was then extracted with ether and the ether extracts were washed with water and then dried over sodium sulphate. Concentration of the solution gave the crude quinone, which was purified by passing through a short column of silica gel using $1: 1$ chloroform and hexane $\left(40-60^{\circ}\right)$ as eluent. Concentration of the eluate and crystallization of the product gave 2-bromo-6-methyl-1, 4-benzoquinone; yield $6.45 \mathrm{~g}$ $(80 \%)$, m.p. $93^{\circ}$.

\subsection{Oxidation of 2, 4, 6-tribromo-m-cresol: Typical small scale procedure}

A solution of 2, 4, 6-tribromo- $m$-cresol $(\underline{5})(0.69 \mathrm{~g}, 2 \mathrm{~m} \mathrm{~mol})$ in $30 \mathrm{ml}$ of acetonitrile is added to the solution of potassium peroxydisulphate $(1.08 \mathrm{~g}, 4 \mathrm{~m} \mathrm{~mol})$ in $20 \mathrm{ml}$ of water and copper sulphate $(0.055 \mathrm{~g}, 0.22 \mathrm{~m} \mathrm{~mol})$. The resulting yellow mixture is stirred at 70 $80^{\circ}$ for $1 \mathrm{~h}$. The reaction mixture is extracted with ether. The extract, after drying, is distilled to remove the solvent. The product is separated by TLC using 1:1 chloroform/hexane $\left(40-60^{\circ} \mathrm{C}\right)$; yield $448 \mathrm{mg}(80 \%)$, m.p. $116^{\circ}$.

\subsection{Oxidation of 2,4-dibromothymol with potassium bis(biureto)-cuprate(III) ( $\left.\mathrm{KCu}(\mathrm{NH} . \mathrm{CO} . \mathrm{NH} . \mathrm{CO} . \mathrm{NH})_{2}\right)$ : Typical small-scale procedure}

A solution of 2, 4-dibromothymol ( $(\underline{3})(0.3 \mathrm{~g}, 1 \mathrm{~m} \mathrm{~mol})$ in $30 \mathrm{ml}$ of acetonitrile is added to the solution of potassium bis-(biureto)cuprate(III) $(1.24 \mathrm{~g}, 4 \mathrm{~m} \mathrm{~mol})$ in $20 \mathrm{ml}$ of water. 
The resulting brown colour mixture is stirred at $70-80^{\circ} \mathrm{C}$ for $2 \mathrm{~h}$. The reaction mixture is extracted with ether. The extract, after drying, is distilled to remove the solvent. The product is separated by TLC using $1: 1$ chloroform/hexane $\left(40-60^{\circ} \mathrm{C}\right)$; yield $163 \mathrm{mg}$ $(67 \%)$, m.p. $46^{\circ}$.

\section{References}

Albert H E $1954 \mathrm{~J}$. Am. Chem. Soc. 764983

Bacon R G R, Grime R and Munro D J 1954 J. Chem. Soc. 2275

Bacon R G R and Izzat A R 1966 J. Chem. Soc. C 791

Bacon R G R and Munro D J 1960 J. Chem. Soc. 1339

Baker W and Brown N C 1948 J. Chem. Soc. 2303

Barton D H R, Brewster A G, Ley S V and Rosenfeld M N 1976 J. Chem. Soc., Chem. Commun. 985

Barton D H R, Ley S V, Magnus P D and Rosenfeld M N 1977 J. Chem. Soc., Perkin I 567

Barton D H R, Magnus P D and Quinney J C 1975 J. Chem. Soc., Perkin I 1610

Behrman E J 1963 J. Am. Chem. Soc. 853478

Claus A and Jackson V A 1888 J. Prakt. Chem. (2) 3832

Elbs K 1893 J. Prakt. Chem. 48179

Finkbeiner H and Toothaker A T 1968 J. Org. Chem. 334347

Gadd D F, Hunns A B and Richardson M A 1977 Educ. Chem. 14145

Haynes C G, Turner A H and Waters W A 1956 J. Chem. Soc. 2823

Heinichen O 1889 Liebigs Ann. 253267

Horswill E C and Ingold K U 1966 Can. J. Chem. 44 263, 269

Inove H, Simamura O and Takamizawa K 1962 Bull. Chem. Soc. Jpn. 351958

Jost H and Richter F 1923 Chem. Ber. 56119

Kehrmann F 1889 Chem. Ber. 223263

Kehrmann F and Kruger O 1900 Liebigs Ann. 31089

Kuczenski R $1973 \mathrm{~J}$. Biol. Chem. 2482261

Ling A R 1892 J. Chem. Soc. 61558

Mayer A M and Harel E 1979 Phytochemistry 18193

McElavain S M and Englehardt E L 1944 J. Am. Chem. Soc. 661077

McKillop A, Swann B P and Taylor E C 1970 Tetrahedron 264031

Meldola R and Hughes F $1890 \mathrm{~J}$. Chem. Soc. 57393

Moore R F and Waters W A 1952 J. Chem. Soc. 2432

Ogata Y and Akada T 1970 Tetrahedron 26594

Orton K J P, Coates J E and Burdett F 1907 J. Chem. Soc. 9147

Perumal P T and Bhatt M V 1979a Tetrahedron Lett. 3099

Perumal P T and Bhatt M V 1979b Synthesis 205

Raiford L C 1911 Am. Chem. J. 46417

Taylor W I and Battersby A R 1967 Oxidative coupling of phenols (New York: Marcel Dekker)

Teuber H J and Staiger G 1955 Chem. Ber. 88802

Teuber H J and Rau W 1953 Chem. Ber. 861036

Walling C and Hodgdon Jr R $1958 \mathrm{~J}$. Am. Chem. Soc. 80228

Woolf L I 1963 Advances in clinical chemistry (New York, London: Academic Press) vol 6, p. 97

Zincke Th and Janney N W 1913 Liebigs Ann. 398354 